\title{
Questioning on consistency of a Stagnation Scale in Medication Overuse Headache: one more added to a plea of emperor's clothes?
}

\author{
Marco Innamorati ${ }^{1}$, Maurizio Pompili ${ }^{1 *}$ and Paolo Martelletti ${ }^{2}$
}

\section{Correspondence/Findings}

With great pleasure we write this Reply letter to the considerations, all of them indeed very interesting and thought-provoking, from Crombez relatively to a paper of validation of an existing instrument suitable/appropriate to our vision of a chronic migraine patient's complexity [1].

The author uses a much ironic and opinionated style [2], obviously supported from his undisputed experience in the study of psychology of pain but with an undisputed limited experience in the study of chronic migraine and its complications (such as Medication Overuse Headache $[\mathrm{MOH}])$ as well $[3,4]$, a clinical area very variegated with multiple medical comorbidities, not only psychopathological ones [5]. His letter is specifically premeditated, providing a pulpit to widen the debate on the questioned attempt [4].

Firstly, the validity of the original test, the Stagnation Scale, has been widely confirmed and it is not our duty to re-discuss it, but maybe only to choose what to validate, its Italian version. Let's proceed with order.

The presence of emotional disturbances has been used to distinguish complicated cases of $\mathrm{MOH}$ (MOH Type II) [6-8] and although, it is necessary to screen $\mathrm{MOH}$ patients for anxiety and depression [9] psychological pain presentation might be multifaceted. Stagnation is a traditional Chinese medicine syndrome characterized by a cluster of mind/body obstruction-like symptoms such as feeling that something is stuck in the throat, chest and stomach, preoccupation or fear of losing what one possesses, and/or being unable to let go of some matters [10]. The construct of stagnation may capture some aspects of the psychological pain experienced from the individual that other Western

\footnotetext{
* Correspondence: maurizio.pompili@uniroma1.it

'Department of Neurosciences, Mental Health and Sensory Organs, Suicide Prevention Center, Sant'Andrea Hospital, Sapienza University of Rome, Rome, Italy

Full list of author information is available at the end of the article
}

construct such as depression, anxiety or somatization are not able to capture.

$\mathrm{Ng}$ et al. [11-14] operationalized the construct of stagnation through the development of the Stagnation Scale with the help of experts in traditional Chinese medicine [11]. In their initial studies, the authors obtained data suggesting that Stagnation is a clinical syndrome distinct from depression [11]. Following the studies conducted on Chinese samples, we hypothesized the utility of the Stagnation Scale also in patients with chronic headache and conducted a pilot study in a small sample of chronic migraine patients [15]. This study indicated that stagnation severity was associated with higher perceived disability independent of the severity of depression, and that it could be useful for predicting perceived disability among patients with chronic migraine [15]. These promising results suggested us to study the psychometric properties of the Stagnation Scale, the first step in the utilization of this scale to study the usefulness of the construct of Stagnation in larger samples of chronic headache patients.

Lastly, without using journalistic exhumation of false and non-existing emperor's new clothes, we do not believe we are able to scare anyone to the point of being silent in front of a blatant fake. Therefore we thank the author for giving us the possibility to do justice to the concept that we shall not loose the spirit, curiosity and courage to look far, considering chronic migraine not like an assemblage of sealed compartments but as a perfect model for a multimodal approach.

In conclusion, it is more than certain that doing more does not mean doing better, but it is also true that as Marcel Proust said "even the wisest of doctors are relying on scientific truths the errors of which will be recognized within a few years". We accept these limits, totally. 


\section{Competing interests}

The authors declare that they have no competing interests.

\section{Authors' contributions}

All authors have equally contributed to the manuscript.

\section{Acknowledgements}

All the authors did not receive any kind of direct or indirect compensation in preparing this manuscript.

\section{Author details}

${ }^{1}$ Department of Neurosciences, Mental Health and Sensory Organs, Suicide Prevention Center, Sant'Andrea Hospital, Sapienza University of Rome, Rome, Italy. ${ }^{2}$ Department of Clinical and Molecular Medicine, Sapienza University of Rome and Regional Referral Headache Centre, Sant'Andrea Hospital, Rome, Italy.

Received: 19 January 2015 Accepted: 26 January 2015

Published online: 11 February 2015

\section{References}

1. Innamorati M, Pompili M, Erbuto D, Ricci F, Migliorati M, Lamis DA, Amore M, Girardi P, Martelletti P (2015) Psychometric properties of the Stagnation Scale in medication overuse headache patients. J Headache Pain 16:10

2. Crombez G (2015) About stagnation and emperor's new clothes. J Headache Pain 16:11

3. Lauwerier E, Paemeleire K, Van Damme S, Goubert L, Crombez G (2011) Medication use in patients with migraine and medication-overuse headache: the role of problem-solving and attitudes about pain medication. Pain 152:1334-1339

4. Negro A, Martelletti P (2011) Chronic migraine plus medication overuse headache: two entities or not? J Headache Pain 12:593-601

5. Tana C, Tafuri E, Tana M, Martelletti P, Negro A, Affaitati G, Fabrizio A, Costantini R, Mezzetti A, Giamberardino MA (2013) New insights into the cardiovascular risk of migraine and the role of white matter hyperintensities: is gold all that glitters? J Headache Pain 14:9

6. Saper JR, Lake AE 3rd (2006) Medication overuse headache: type I and type II. Cephalalgia 26:1262

7. Lake AE 3rd (2006) Medication overuse headache: biobehavioral issues and solutions. Headache 46(Suppl 3):S88-S97

8. Rossi P, Faroni JV, Nappi G (2011) Short-term effectiveness of simple advice as a withdrawal strategy in simple and complicated medication overuse headache. Eur J Neurol 18:396-401

9. Maizels M, Smitherman TA, Penzien DB (2006) A review of screening tools for psychiatric comorbidity in headache patients. Headache 46(Suppl 3): S98-S109

10. Yuen YC, Ren JS, Wang L, Guo KZ (1997) Chinese-English dictionary of traditional Chinese medicine. People's Health Publishing, Beijing

11. Ng SM, Chan CLW, Ho DYF, Wong YY, Ho RTH (2006) Stagnation as a Distinct Clinical Syndrome: Comparing 'Yu' (Stagnation) in Traditional Chinese Medicine with Depression. Br J Soc Work 36:467-484

12. Ng SM (2008) Operationalising Chinese medicine 'stagnation' concept as a psychological construct. Hong Kong J Psychiatry 18:52

13. Ng SM, Fong TCT (2011) The use of a structured questionnaire to study stagnation syndrome in traditional Chinese medicine among adults living in community. J Chinese Integ Med 9:22-28

14. Ng SM, Fong TC, Wang XL, Wang YJ (2012) Confirmatory factor analysis of the stagnation scale-a traditional Chinese medicine construct operationalized for mental health practice. Int J Behav Med 19:228-233

15. Innamorati M, Pompili M, Fiorillo M, Lala N, Negro A, Del Bono SD, Lester D, Girardi P, Martelletti P (2013) Overattachment and perceived disability in chronic migraineurs. Clin Neurol Neurosurg 115:954-958

\section{Submit your manuscript to a SpringerOpen ${ }^{\odot}$ journal and benefit from:}

- Convenient online submission

- Rigorous peer review

- Immediate publication on acceptance

- Open access: articles freely available online

- High visibility within the field

- Retaining the copyright to your article

Submit your next manuscript at $>$ springeropen.com 